\title{
THE INTERPRETATION OF THE N. I. L. AND STATUTES DECLARING INSTRUMENTS VOID
}

\author{
Frederick K. Beutel $†$
}

When a legislature fias declared that certain acts or activities resulting in agreements are socially undesirable and therefore tainted with illegality, a number of results may follow. So far as their enforcement is concerned agreements made contrary to such statutes may be illegal, voidable or void.

The standard texts have it that if they are "merely illegal" they are unenforceable between the parties; if "voidable" they may be enforced unless the injured party objects; but if "void" they are of no effect at all. ${ }^{1}$ As long as the interests of the original parties and the purpose of the legislative command which is usually enacted with them in mind are involved, this classification is satisfactory enough; but when the prohibited, illegal, or void act touches third persons, this analysis needs further examination.

One of the most interesting of such situations, and one which seems to have caused much confusion, apparent as weli as real, in the decisions, is that in which the interests of a holder in due course of a negotiable instrument run counter to a statute declaring the instrument which he has purchased defective because, at some point in its life, either at inception or transfer, some of its apparent parties have violated the legislative command.

Since the holder in due course is an especially favored party, mere illegality is seldom recognized as a defense against him. ${ }^{2}$ So also the right to avoid is usually restricted to the immediate parties to the transaction, but the holder in due course is allowed to recover in almost all cases. ${ }^{3}$

The real difficulties arise in those cases where the legislature in its wisdom has seen fit to declare that the instrument, because of the part which it has played in the prohibited transaction, is "void", or has employed some

$\dagger$ A.B., I921, Cornell University; LL.B., I925, S. J. D., I928, Harvard University; editor, Brannan, Negotiable Instruments LAw (5th ed. I932) ; Professor of Law, Tulane University.

I. 2 Williston, Contracts (I920) §II59; 3 id. §§ I628-1630; I Daniei, Negotiable INSTRuments (7th ed. I933) \$\$227, 229; Byles, BiLls (4th Am. ed. 1856) 205; Storx, BIILS OF EXCHANGE (2d ed. I846) \$\$ I89, igo.

2. For an excellent discussion of the common law on this point see Daniex, Negotiable INSTRUMENTS (4th ed. I89I) $\$$ I87 et seq.; STORX, loc. cit. sitpra note I. For cases since the Act to the same effect, see Brannan, NEGotiable Instruments Law (5th ed. I932) 555 et seq., and authorities there cited; Note L. R. A. I9I8C 775 et seq.

3. The cases involving incapacity, especially that of infancy, form an exception to this rule. See Negotiable Instruments Law \$ 22 ; Brannan, op. cit. supra note 2, at 277 et seq.; cf. SALES ACT $\$ 24$. The reasons for the exceptions as to capacity are discussed infra p. 763 . But where the instrument is voidable for illegality, the rule is as stated. Bank of of Youngsville v. Hunt, I88 N. C. 377 , I24 S. E. 854 (1924). 
synonymous expression. ${ }^{4}$ This paper will be devoted entirely to discussing this aspect of the general problem.

\section{The Meaning of the Term "Void" as Used by Legislatures}

The expression "void" and its equivalents, as distinguished from "voidable", are usually taken to mean entirely without effect, but a reference to any standard legal dictionary ${ }^{5}$ will reveal that even the courts, to say nothing of legislatures, do not always make the distinction.

The courts and legislatures are prone to use such expressions as "void between the parties", "absolutely void", " "void between the parties and their assigns", "void as to all subsequent parties" 9 and the like. In fact it was not until the late nineteenth century that a clear distinction between void and voidable, null and nullable appeared in such carefully drawn legislation as the civil codes of European countries. ${ }^{10}$ It can hardly be expected, therefore, that an American legislature made up of politicians, rural lawyers, farmers and business men could use the term "void" in an accurate sense to mean "absolutely without effect as to any parties", "entirely null" or the like. Any person who applies such an a priori meaning to the term is guilty of a type of naive logolatry which does irreparable damage to the true legislative intent.

Prima facie then, when a statute declares an instrument void it may be taken to mean one of at least two things: narrowly interpreted, unenforce-

4. See IoWA CODE (193I) $\$ 9407$ : "If it shall be ascertained in any action brought on any contract. . . and in no case where unlawful interest is contracted for shall the plaintiff have judgment for more than the principal sum" (italics added); ALA. CODE (I928) \$ 8567: "and cannot be enforced either at law or in equity. . . . Nor shall the borrower . . . ever in any case in law or equity be required to pay".

5. 3 Bouvier, Law Dictionary (3d ed. I9I4) 3406 ef seq.; Black, Law Dictionary (2d ed. I933) 1822; SHUMAKER AND LONGSDORF, CYCLOPEDIC LAw DictionARY (2d ed. 1922) I064.

6. See 2 OREGoN CODE (I930) $\$ \S 43$-IOI ("void and of no effect as between the parties to the same and all other persons, except holders in good faith, without notice") ; Matlock v. Scheuerman, 5 I Ore. 49, 52; 93 Pac, 823, 825 (1908); IrL. Rev. STax. (Cahill, I933) c. 32, $\$ 290$ ("void at the election of the purchaser"); McGregor v. Lamont, 225 Ill. App. $45 I$ (I922).

7. ARK. Dig. Stat. (Crawford \& Moses, I921) \$7956, which adds "and no person shall be considered an innocent holder of the same, though he may have given value . . before maturity"; Iowa CODE (I93I) § 9442; S. D. CoMr. LAws (I929) § 3929; and see Wyatt v. Wallace, 67 Ark. 575, 576, 55 S. W. II05, 1106 (1900) ; ArA. CoDE (1907) \$3653 ("null and void") ; CAL. GEN. Laws (Deering, 193I) Act 3757, \$2 (same) ; Ky. Acts 189I-1893, § 34 (3) (same) ; N. Y. Cons. Laws (Cahill, 1930) c. 40, §993 ("utterly void"); 9 ANNE c. I4, \$ I (I7I0) ("void as to all intents and purposes whatsoever").

8. N. D. REv. CoDE (1899) $\$ 3265$; National Bk. of Commerce v. Pick, I3 N. D. 74, 99 N. W. 63 (1904); and see FLA. Comp, LAws (I907) c. 5717 ("void on its behalf and on behalf of its assigns"); Commercial Bank y. Jordan, 7 I Fla. 566, 71 So. 760 (IgI6).

9. Coro. Comp. Laws (I92I) $\$ 6869$ ("void [and] no assignment . . shall in any manner offset the defense . - or the remedies of any person interested therein"); UTAB REv. STAT. (I933) tit. I8, c. $8, \$ 5$ ("wholly void on behalf of such corporation and its assignees and every person deriving any interest or title therefrom, but shall be valid and enforceable against such corporation, assignee and person") ; National Bk, of the Republic v. Price, 65 Utah 57, 63-65, 234 Pac. 23I, 234 (1925); see ARK. DIG. STAT., note 7, stipra.

10. See Scruster, Principles OE German Law (1907) 8r et seq.; I Planiol ET Ripert, Tratte Elémentaire DE Droit CIV!̣ (IIth ed. 1928) Nos. 328, 329, 330, 332; C Hung Hui Wang, German Civit Code (I907) 600 . 
able between the parties (a sort of defense of illegality); broadly interpreted, without any effect, null and void as to the whole world. The problem at the outset, then, becomes one of statutory interpretation and construction.

\section{The State of the Law Before the N. I. L.}

Before the enactment of the Negotiable Instruments Law, the problem was usually simple. Since most of the law of negotiable instruments was still uncodified, the courts had to deal with the effect of a single statute on the rights of a bona fide purchaser before maturity, as to whom the law had not yet crystallized into codified form. In these statutes the legislature had singled out particular transactions to condemn, such as gambling, lending money at high rates of interest and the like. The purchase of a negotiable instrument by a subsequent bona fide purchaser was outside of the prohibited transaction. By a narrow construction of the statute, the court deciding the suit between the holder in due course and the maker easily could rely on the equities, pointing out that the maker was really a party to the wrongful act and that the holder was an innocent party who would suffer loss as a result of the maker's wrong if he were not allowed to collect on the paper. Persuaded by these considerations, the court could easily hold that the statute meant "void as between the parties only".

On the other hand, it might be argued with equal force that the prohibitory statutes were designed to protect the maker, that if the bona fide purchaser could recover, this purpose would be defeated; and the wrongdoer, the professional gambler or usurer, as the case might be, would be enabled to consummate his illegal acts with the proceeds of the instrument which he received from the bona fide purchaser. To prevent this result no recovery should be allowed, and the bona fide purchaser should be remanded to his rights against his vendor on the indorsement. Such a result might be classed as a broad interpretation of the statute by applying it to circumstances not contemplated by the legislature. Considering the fact also that the legislature had chosen the term "void" instead of "illegal" or "voidable" it is not surprising that the courts adopted the broad interpretation suggested in the latter line of reasoning to reach the result that the instrument was "utterly void $a b$ initio" and that no life could be breathed into it by later transactions so as to hold the original maker. ${ }^{11}$ Thus under the Statute of Anne ${ }^{12}$ on gambling and the New York usury laws ${ }^{13}$ declaring the instruments void, it was not surprising to find the courts holding them "entirely void" even in the hands of bona fide purchasers. ${ }^{14}$ In fact this was so well established that illegality

II. Note L. R. A. 19I8C 773 et seq.; STORY, op. cit. supra note I, at 225; BYLEs, op. cit. supra note $\mathrm{I}$, at 207.

I2. 9 ANNE C. I4, § I (I7IO).

13. N. Y. Cons. Laws (Cahill, 1930) c. $21, \S 373$.

I4. Bowyer v. Bampton, 2 Strange II55 (K. B. I795); Shillito v. Theed, 7 Bing. 405 (C. P. I83I) ; Claflin v. Boorum, I22 N. Y. 385,25 N. E. 360 (I890). 
of this sort was often classed as a real defense at common law. ${ }^{15}$ But though the broad interpretation was the more persuasive and represented better statutory construction, it was not entirely unanimous, and there was excellent authority even under the common law applying the narrow construction of the penal statute and allowing recovery in favor of the bona fide purchaser before maturity. ${ }^{16}$

\section{Can a Statute Make a Void Instrument Valid in the Hands of "Subsequent Purchaser"?}

These latter minority decisions have been criticised on the ground that in the nature of things if an instrument is void it is non-existent and cannot get life by subsequent transactions in which the maker takes no part. ${ }^{17}$ Arguments of this sort also may proceed from a kind of biological analogy that when a thing is once dead it remains dead, or perhaps they rest on a metaphysical concept that when a thing is void it is nothing, and it is impossible to make something out of nothing.

Such arguments are put to the acid test when one encounters a jurisdiction where one statute makes contracts void because issued for an illegal or prohibited purpose and another statute makes negotiable instruments valid against all defenses in the hands of a subsequent bona fide purchaser.

The logician, metaphysician or those adopting the biological analogy are hard pressed by a statutory situation such as existed in South Dakota both prior to ${ }^{18}$ and after ${ }^{19}$. the adoption of the N. I. L. The South Dakota Code of Igrg referring to gaming provided:

"Any note, bond or other contract made and entered into, where the whole or any part of the consideration thereof shall be for money or other valuable thing, won or lost, laid, staked or betted at or upon any game of any kind, under any name or by any means; or for the repayment of money or other thing of value, lent or advanced, at the time and for the purpose of any game, play, bet or wager, or being laid, staked, betted or wagered thereon shall be absolutely void." 20

I5. See Brannan, Negotiable Instruarents Law (4th ed. 1926) 440 et seq.; Danforth, Illegality Under the Negotiable Instruments Law (I92I) 92 CENT. L. J. 27; 2 Winliston, Contracts (1920) § 1158; Green, Real Defenses and the Negotiable Instruments Law (1934) 9 TULane L. Rev. 78.

16. Ewell v. Daggs, I08 U. S. I43 (I883) ; see Sondheim v. Gilbert, II7 Ind. 7I, 80, IS N. E. 687,691 (1888).

17. Danforth, supra note 15 , at 33,37 . The author of this article goes even further and argues that the maker cannot even estop himself by subsequent representations. But the writer himself admits that this is contrary to the cases which he cites and to the weight of authority. Holzbog v. Bakrow, I56 Ky. I6I, I60 S. W. 792 (I913), 50 L. R. A. (N. S.) 1023 (I9I4). This argument is also clearly contrary to the general theory of the N. I. L. See $\$ \$ 23,124$, allowing such estoppel where otherwise the instrument would be void. See also Green, supra note 15 , at 85 et seq.

18. The gaming law (infra note 20) was adopted in 1907. at 1126 .

19. The N. I. L. was adopted in South Dakota in 1913. BrannaN, op. cit. supra note 2,

2.0. S. D. Conp. Laws (I929) § 3929. 
Another section of the same code dealing with negotiable instruments read as follows:

"An indorsee of a negotiable instrument, in due course, acquires an absolute title thereto, so that it is valid in his hands, notwithstanding any provision of law making it generally void or voidable, and notwithstanding any defect in the title of the person from whom he acquired it." 21

It might be argued that the two statutes are contradictory and that the last therefore repeals the former. ${ }^{22}$ The matter is simple enough when the statutes have different dates, but unfortunately both were enacted in the same code. It is a clear canon of statutory construction that in cases of contradiction the special act takes precedence over the general, ${ }^{23}$ but unfortunately the gaming act is special as to gaming but general as to the contracts effected thereby, while the N. I. L. is general as to illegality but special as to negotiable instruments. The case at hand is one of a negotiable instrument given for gaming. Both acts as applied to the facts are special and both general, so that the rule is useless. Under such circumstances, it might be suggested that since the two articles are contradictory on this set of facts both fall out of the code and the court is remitted to the common law. ${ }^{24}$ However, it is a clear canon of statutory construction and common sense that the legislature should not be made to contradict itself if by any reasonable construction the two apparently conflicting statutes can be reconciled. ${ }^{25}$ In this case such a reconciliation is easy. It is possible to argue that the prohibitory statute protecting the maker applies to the contract between the parties and their assigns with notice; but that the purpose of the law on negotiable instruments was to protect the bona fide purchaser by allowing him to rely on the facts appearing from the paper which he purchased. Since the maker created these facts he should be held. Thus each statute is given its primary purpose, and the apparent difficulty vanishes. This interpretation is hard on the logician and metaphysician, but since it serves the purposes of justice in real life it is not surprising that the courts found no difficulty in reaching it. ${ }^{26}$

2I. S. D. Comp. LAws (1929) $\S 1720$. This is $\S I 6$ of the N. I. L. especially amended to cover this situation.

22. This is the usual interpretation of statutes at common law. Maxweld, Interpretation of Statutes ( 7 th ed. I929) I38 et seq.; Dwarris, Treatise on Statutes (Potter's Am. ed. I885) I55 et seq.; Sidon, J. in First Nat. Bk. v. Parker, 57 Utah 290, 294-296, I94 Pac. $66 \mathrm{I}, 665$ (1920). The problem may be greatly complicated by the existence of repealing clauses in the later act. But since this depends upon the particular words of particular acts and involves a totally different type of interpretation, consideration of repealing clauses is omitted.

23. See Garnett v. Bradley, 3 App. Cas. 944, 950 (1878).

24. See Gutteridge, $A$ Comparative Vieze of the Interpretation of Statute Law (I933) 8 TULANE L. REV. 1,6 , and authorities there cited.

25. MAXWEII, op. cit. supra note 22, at I36-I44; DWARRIS, op. cit. supra note 22, at I54, ก. 4 .

26. McCardell v. Davis, 49 S. D. 554,207 N. W. 662 (1926) ; and for the same result under two statutes in Georgia before the N. I. L. creating a similar situation, Howard v. Simpkins, 70 Ga. 322 (1883). 


\section{The Meaning of Section 57 of the N.I. L.}

If the N. I. L. had clearly expressed the intention that all instruments void at inception should be valid in the hands of a holder in due course it would not have expressed a concept foreign to Anglo-American law or difficult of understanding. ${ }^{27}$ Fortunately, however, the Act is not so rashly phrased. Section 57, which is the key to the problem, states:

"A holder in due course holds the instrument free from any defect of title of prior parties, and free from deferises available to prior parties among themselves, and may enforce payment of the instrument for the full amount thereof against all parties liable thereon."

Nothing is said about illegality, but it should be noted that a holder in due course takes free from defects of title, and Section 55, defining defect of title, provides:

"The title of a person who negotiates an instrument is defective within the meaning of this act when he obtained the instrument, or any signature thereto by . . ., or other unlawful means, or for an illegal consideration.

On its face, it would seem that, so far as these two sections are concerned, the Act is susceptible of either of two interpretations: (I) a holder in due course cuts off only personal defenses; or (2) instruments void for illegality are good in the hands of a holder in due course.

The use in Section 57 of the phrase "free from defenses available to prior parties among themselves" might, from an historical point of view, be taken to be only a codification of the common law, which recognized real defenses and the defense of statutory voidability; and "unlawful means" and "illegal consideration" in Section 55 could be taken as a codification of the law as it stood on the point and no more, "defects of title" being simply substituted for the common law terminology, "personal defenses". It might be argued also that the holder in due course can hold only "parties. liable thereon" and that the maker is not liable since the instrument was void. This line of argument will be recognized at once as a narrow construction of the statute. $^{28}$

On the other hand, it may be argued with equal force that the words "all parties liable thereon" mean persons who appear to be liable on the face of the instrument (as the holder in due course sees it). The holder in due course under this interpretation of Section 57 would take free from defects

27. See Ewell v. Daggs, ro8 U. S. 143 (1883); and authorities cited notes 20, 21, 26, supra.

28. This narrow construction is supported by most of the older writers trained in the recent common law methods of interpretation. See 2 WIILISTON, CoNTRACTS (I920) § II59; BranNan, Negotrable Instruments Law (Chafee's 4th ed. 1926) $44 \mathrm{I}$; but $c f$. id. (Beutel's 5th ed. I932) 556. 
of title as defined in Section 55, and the reference to "defenses available to prior parties among themselves" would apply to payment, suretyship defenses, and the like. ${ }^{29}$ Section 55 in defining "defects" uses the very broad terms, "duress, or force and fear, or other unlawful means, or for an illegal consideration". Surely when one takes an instrument in a situation prohibited by law he obtains it by "unlawful means" and for an "illegal consideration", and since the statute does not distinguish between various kinds of illegality, it might be taken to cover them all. This broad interpretation, of course, would achieve the same result as the South Dakota statute, and would make the instrument valid in the hands of the holder in due course.

The history of the Act offers little to clear up this ambiguity except that the argument for the broad interpretation may be strengthened slightly by the fact that the draftsman in copying the Bills of Exchange Act, Section 38 (2), omitted the words "mere personal" when speaking of cutting off "defenses available to prior parties among themselves". ${ }^{30}$ Prima facie, this omission would tend to show intention of the N. I. L. to cut off other than personal defenses. Unfortunately the draftsman's notes explaining the changes from the British Act, and the proceedings of the Saratoga meeting at which the N. I. L. was discussed and approved are not available. ${ }^{31}$

The Ames-Brewster controversy and contemporary writings explaining the Act throw little light on the intention of the framers on this point. ${ }^{32}$ Judge Brewster ${ }^{33}$ speaks approvingly of Wirt $v$. Stubblefield, ${ }^{34}$ discussed below, which is a square adoption of the previous minority rule. ${ }^{35}$ Crawford,

29. See Negotiable Instruments Law $\$$ IIg (4), I20, I22; Brewster, $A$ Defense of the Negotiable Instruments Laze (Ig00) Io YALE L. J. 84, 94, reprinted' in BRANNAN, NEGoTIABLE INSTRUMENTS LAw (2d ed. I9II) I79, I89; Eaton, The Negotiable Instruments Law (1904) 2 MICH. L. REv. 260, 276 et seq., citing with approval Farrell, The Negotiable Instrumients Law (I900) 3 The BRIEF of PHI DeITA PHI. See also Beutel, The Meaning of the Term "Principal Debtor" as used in the N. I. L. (April, I934) PA. BAR Q. 206.

30. See Chalmers, Bills of Exchange (gth ed. I927) 146; cf. BRANNAN, op. cit. supra note 2 , at 619,559 , and authorities there cited.

31. These notes are mentioned by McKeehan, The Negotiable Instruments Law ( $A R e-$ viewe of the Ames-Brewster Controversy) (I902) 50 U. of PA. L. REv. 437, 439, and are reproduced in part at least, if not in full, in Huffcut, Negortable INSTRUMents (Ist ed. I898) 5-8I; but this report throws no light on the problem involved here. Since this article went to press, the writer has discovered a manuscript copy of Crawford's notes in the Harvard Law Library; but he has as yet been unable positively to identify it as the official draft. These contemporary discussions are of the greatest value in determining legislative intent.

32. The Ames-Brewster controversy in the HaRvard LAw Review and the Yale Law JournaI have been reprinted in full in the first three editions of BranNan, Negotrable INSTRUMENTS LAW. To these should be added, as of even greater value for source material, Eaton's two articles on the N. I. L.: (I904) 2 Mich. L. REv. 260; (Igr3) I2 id. 89; Farrell, supra note 29; CrawFord, Negotiable InStruments Law (Ist ed. I897). None of these, however, can equal in value the actual debate of the Commission. The writer would greatly appreciate any suggestion as to the location of these materials.

33. Reply to supplementary note, Brannan, Negotiable Instruments Law (2d ed. I9II) $217,218$.

34. I7 App. D. C. 283 (Ig00).

35. It is interesting to note in this respect that Judge Brewster reported in Uniform State Lazes (1898) 2I A. B. A. REP. 315, 322, that wherever there was a split of authority on a point the Commission attempted to adopt the rule of the Supreme Court. But there is no evidence, other than inference from this statement, to show whether or not $\$ \$ 55$ and 57 of the N.I. L. were intended to adopt the rule of Ewell v. Daggs, I08 U. S. I43 (I883), cited note I6, supra. 
the draftsman, in the first edition of his work, does not mention the problem, but in a later edition ${ }^{36}$ expresses the opinion that the solution of the question should be left to the public policy of the states. These ex post facto statements are at the best only slight indications of the true intent of the framers, and are far from conclusive.

An examination of other sections of the N. I. L. will show that the concept of the broad interpretation, that an instrument entirely without effect or even inception may be valid in the hands of a holder in due course, is not foreign to the Act. Section I6 provides that an instrument although "incomplete and revocable" for lack of delivery is enforceable in the hands of a holder in due course, thus abolishing the common law real defense of absence of delivery. ${ }^{37}$ Section 14 provides that an instrument issued with blanks "in order that it may be enforced" must be "filled up strictly in accordance with authority given"; but nevertheless it is enforceable for any amount in the hands of a holder in due course. Sections II9 to I22 make it possible for a holder in due course to collect on a discharged instrument, thereby abolishing another common law real defense. ${ }^{38}$ It might be objected that these sections are not good analogies because the Act does not use the term void; but Section $124{ }^{39}$ provides that while in case of alteration the instrument is "avoided", nevertheless in the hands of a holder in due course it springs to life and is again enforceable, another departure from the common law. ${ }^{40}$

These sections then show the intention expressed in the Act that a holder in due course may rely upon the instrument as it appears on its face, if that appearance was in fact caused by the party defendant, even though such defendant was not legally liable on the instrument before it came to the holder. If this principle should be applied to the facts under consideration,

36. Crawford, Necotiable Instruments Law (3d ed. ig08) 7 I et seq.

37. I Daniet, Negotiable Instruments (7th ed. 1933) \$69; Brannan, Negotiable INSTRUMENTS LAW (4th ed. 1926) 432.

38. Ibid. That discharge is now a personal defense seems clear. Brewster, A Defense of the Negotiable Instruments Law (1900) Io YALE L. J. 84; Eaton, The N. I. L., Its History and Its Practical Operation (I904) 2 MrCH. L. REv. 26I, 276, 277; BraNNAN, op. cit. supra note 2, at 558 ; $c f$. NEGOTIABLE INSTRUMENTS LAW $\$ \S 57,121$, 122. The only argument to the contrary to be drawn from the Act springs from Section 47: "An instrument negotiable in its origin continues to be negotiable until it has been restrictively indorsed or discharged by payment or otherwise" (italics are the writer's). From this section it may be argued that after discharge the instrument is non-negotiable, so that discharge becomes a real defense and a subsequent holding in due course is made impossible. It should be noted that the Section provides only for continued negotiability before these facts, $i$. e., restrictive indorsement or discharge, non constat that the condition would be different afterwards, especially when other sections of the act demand a different interpretation. See especially Section 122. Discharge was held a personal defense in Manchester v. Parsons, 75 W. Va. 793, 84 S. E. 885 (rgr5). See comment on Trietel v. Gibson, I3I Misc. 377, 226 N. Y. Supp. 603 (Sup. Ct. 1928), in BRANNAN, op. cit. supra note 2 , at 9II.

39. "But when an instrument has been materially altered and is in the hands of a holder in due course, not a party to the alteration, he may enforce payment thereof according to its original tenor."

40. Voris v. Birdsall, 62 Okla. 286, I62 Pac. 95I (1917) ; Hecht v. Shenners, 126 Wis. $2 \%, 105$ N. W. 309 (1905). 
it would seem that the broad interpretation not only is not opposed to the law of negotiable instruments as codified by the Act, but also seems to fit better than the narrower construction which assumes, contrary to fact, that the Act codified the common law without change. ${ }^{41}$

It should be noted, however, that this broad interpretation is not absolutely required by the Act. The analogies, though persuasive, are neither compelling nor conclusive. Both interpretations are still possible. Which one should be adopted has wisely been left to the courts to be determined upon other considerations or "equities", such as the intent of the parties, the hardships resulting from the given situation, and the public policy as indicated by the legislature in its acts on illegality, which also, as has been shown, may be subject to more than one interpretation.

In its final analysis, the question then becomes a problem of judicial evaluation of legislative policies projected against the background of the facts of particular cases. The framers of the N I. L. easily might have achieved certainty by providing that instruments roid for illegality should nevertheless be valid in the hands of a holder in due course. But it is submitted that problems arising out of situations involving illegality are necessarily so complex and touch so many interests that here is a proper place for the judicial administration of flexible standards rather than for an application of inflexible rules of law. Most of the irreconcilable confusion in the cases in this field has been due to the courts' search for simple rules of law and to the failure to appreciate their duty to administrate legislative standards. An examination of the legislative policy behind the statutes and their effect upon the courts will serve to illustrate this point.

\section{The Condition of Source Materials for Determining Legislative Policy}

In determining the true meaning of legislation and the policy behind it many factors are involved. In addition to the text of the statute and its title and preamble, there are the legislative history of the bill, the debates on the floor of the legislature, the committee hearings, the amendments offered and rejected and adopted, the executives' messages accompanying the submission of a legislative program or a veto, the purpose of the organization which drafted the particular bill or lobbied for it; all may have a pertinent bearing

4I. The assumption that the N. I. L. codified the common law embodies two fallacies, one of fact and another of legal application. As a matter of fact, it is common knowledge that the N. I. L. made many changes, too numerous to list here, in the usually accepted common law rules. Many of Dean Ames' objections were founded on this ground. In addition see CrawFORD, Negottable Instruments Law (Ist ed. I897) iii; McKeehan, The Negotiable Instriments Law (1902) 50 U. of PA. L. REv. 437, 440. As a problem of practical legal application, there was no common law to codify; only the common law of over fifty jurisdictions which differed in the holdings of their courts so radically that codification was forced upon an unwilling profession as a matter of commercial necessity. Whenever a court indulges in the argument that the N. I. L. is the codification of the common law, it is simply rationalizing a return to its own decisions in its particular jurisdiction. Much of the confusion in the cases since the N. I. L. is due to this wholly unwarranted and fallacious method of statutory construction. See Bettel, The Necessity of a New Technique of Interpreting the N.I. L. (I93I) 6 TULANE I. REV. I, 6. 
on the true meaning of the statute and the policy which it attempts to effectuate. In the case of a uniform law the proceedings of the commission and the draftsman's notes also offer invaluable source material. ${ }^{42}$

Unfortunately, legislative material in the United States is so inaccessible, so carelessly assembled and so poorly indexed that a busy practicing lawyer considers himself lucky if he can find the text of the current statute. With the possible exception of acts of Congress, legislative history in most cases seems to be beyond the reach of even the most careful legal scholar. It is small wonder then that the courts have floundered in the maze of legislative variation, often turning for convenience, but nevertheless erroneously and irrelevantly, to the concepts of the common law or to previous decisions to discover the meaning of acts of the legislature:

Although the art of legislative interpretation in this country is greatly handicapped by the absence of an American Digest System for legislation, the situation is not so hopeless as the results of the cases might indicate. Proper attention to relevant factors of the problem can go a long way towards relieving the difficulty.

\section{Statutes for the Protection of Public Order}

Statutes declaring instruments void fall generally into two classes: (I) those passed to protect the public order, and (2) statutes designed primarily to protect individuals or classes of people from greed, trickery, or business advantages held by others.

\section{A. Gaming Statutes}

The oldest and most numerous statutes directed toward the protection of public order are those declaring void contracts made in gambling, and, strange to say, it is in this field that the court decisions have proved the most unsatisfactory.

Viewed from the point of view of statutory policy and the equities involved, it would seem that a holder in due course should be allowed to recover unless the statute expressly declared the instrument to be void in his hands. The purpose of the gambling statute is, of course, to discourage gambling, and in attempting to do so it declares the instrument given for money won at play void. The purpose of the N. I. L. is to protect the innocent purchaser. The reconciliation of policies seems simple, the statute on

42. It is unfortunate that there is no record of the committee hearings, and that the delibcrations of the Uniform Laws Commission, when discussing a law, are carried on in the committee of the whole and are unpublished. The draftsman's notes published with the later copies of the uniform laws tend, to some extent, to alleviate this difficulty, but there is nothing which even approaches the discussions of the French Civil Code. See FENET, ReCEUIL COMPLET DE Travaux Préparationes du Code Crvit (1827) in fifteen volumes; Fenet, Motifs et Discours du CODE CIVIL (1850) in two volumes; Locré, La LéGislation de LA France (I827) in thirty-one volumes. Unfortunately, Americans labor under the fallacious belief that when a law is reduced to writing it is clear. Apparently, all the similar valuable material for the American Law Institute's Restatements is also being displaced by a lot of local annotations, which will immediately start to defeat the unifying effect of the Restatements. 
gaming should be held to apply to the gamblers and their assignees; but the holder in due course should recover. In this way the gambler is made to bear the loss and not the innocent holder. ${ }^{43}$ Thus the purpose of the gaming statute to discourage gambling is also achieved. It seems equally clear that, on the equities, the innocent holder should be protected against the wrongdoing maker who has caused the situation by violating the statute. This was the result achieved by a few of the early and well reasoned decisions under the N. I. L., ${ }^{44}$ but unfortunately the overwhelming weight of authority in the United States is to the contrary. ${ }^{45}$

The leading case which the majority decisions seem to follow is Alcxander \& Co. $v$. Hazelrigg, ${ }^{46}$ involving the interpretation of a Kentucky statute which provided as follows:

"Every contract, conveyance . . . for consideration . . . of money . . . won, lost or bet in any game, sport, pastime, wager, or for consideration of money, property, or other thing lent for the purpose of gaming . . . shall be void." 47

The court, relying upon previous decisions of the state properly holding that the statute before the N. I. L. made the instruments void in the hands of bona fide purchasers, stated that the public policy was well established to this effect. This argument entirely overlooked the fact that the old decisions were no longer the law of the state but were superseded by the codification of the law of negotiable instruments in the new Act. ${ }^{48}$ It also disregarded the fact that the enactment of the N. I. L. is itself an expression of public policy which, coming from the legislature, is more effective than that based upon judicial decisions interpreting previous legislation.

This case and those that follow it also lean very heavily on the doctrine of implied repeal. It is a well established rule that statutes are not repealed by later ones unless they are expressly named in the repealing clause or unless

43. The contrary argumients that if the holder in due course is allowed to recover the winner is more easily enabled to achieve the fruits of his victory, or that if the holder in due course cannot recover gambling with notes will be discouraged is of no force, because by hypothesis the holder in due course knows nothing of the defense of gambling-otherwise he would not be a holder in due course. On the other hand, if the gambler knows that the courts will not enforce his notes he may be encouraged to use them at play, knowing that if he loses he will not have to pay. The right of recourse by the holder in due course against the winner on his endorsement is of little importance, because the maker usually has a similar right under gambling laws, and neither holder nor maker is likely to have much success in finding him.

44. Wirt v. Stubblefield, I7 App. D. C. 283 (I900); Myers v. Kessler, I42 Fed. 730 (C. C. A. 3d, I906) ; Wolford v. Martinez, 28 N. M. 622, 216 Pac. 499 (I923); cf. Citizens' Nat. Bk. v. McDannald, II6 Va. 834,83 S. E. 389 (I9I4).

45. The cases are collected in a series of notes. (I920) 8 A. L. R. 3I4; (I92I) II A. I. R. 2II; (1925) 37 A. L. R. 698; (1927) 46 A. L. R. 959.

46. 123 Ky. 677,97 S. W. 353 (I906).

47. The statute is now KY. STAт. (Carroll, 1930) § 1955.

48. See the excellent discussion to this effect in Wirt v. Stubblefield, I7 App. D. C. 283 (I900), quoted and then ignored by the court. I23 Ky. at $682,683,97 \mathrm{~S}$. W. at 354 . See also Eaton, On Uniformity in Judicial Decisions of Cases Arising Under the N. I. L. (I913) 12 Mich. L. Rev. 89, 9 I. 
they are contradicted by the later statutes. Repeals by implication should be avoided. ${ }^{49}$ On this ground the courts in the majority cases maintain the previous judicial rule and either ignore the N. I. L. or give it the narrow construction..$^{50}$ Their argument is subject to two fallacies. It assumes that the judicial interpretation of the gaming law is part of the older statute, which is not the case, and secondly, it assumes that to change their judicial interpretation is to repeal the gaming statute. There is really no question of repeal involved. The gaming statute still is in force, and it is too clear for argument that no matter what may be the result as to a holder in due course, it still applies as between the parties and to purchasers with notice. The only question involved is the effect of both statutes on the particular problem of the rights of the holder in due course. As has been shown, this is merely a question of adopting an interpretation which, by reconciling both enactments, best fits the purpose of the two statutes and the ends of justice.

Many of the majority. cases rely upon the old aphorism that when a

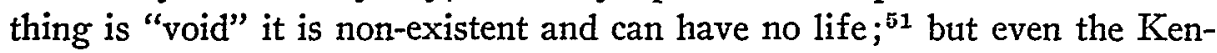
tucky court admits the doctrine of estoppel to make a void instrument valid ${ }^{52}$ even though the estopping facts are contained only in the void instrument itself. $^{53}$ But this doctrine of voidness is put to the acid test when the question of indorsement for a gaming debt under identical statutes is involved. Here the weight of authority swings the other way, ${ }^{54}$ and the indorsement is held good in the hands of a holder in due course. It is submitted that the considerations in both cases are identical, so far as the validity of the indorsement to pass title under a statute reading as follows:

"All things in action, judgments, mortgages, conveyances and every other security whatsoever, given or executed. . . for any money or other thing won by playing at any game whatsoever... shall be utterly void." 55

Yet the cases have held that indorsements for gaming debts pass title under these acts to holders in due course, ${ }^{, 0}$ even though such a holder could not et seq.

49. Dwarris, op. cit. supra note 22 , at 154, n. 4 ; MaXwell, op. cit. supra note 22 , at 136

50. See Alexander v. Hazelrigg, I23 Ky. 677, 97 S. W. 353 (Ig06), cited note 46, supra; Manufacturers \& Merchants Bk. v. Twelfth Street Bk., 223 Mo. App. I9r, I6 S. W. (2d) 105 (1929); Plank v. Swift, I87 Iowa 293, 174 N. W. 236 (1919); Fisher v. Brehm, 10o N. J. L. 345, 346, 126 Atl. 444, 445 (1924); and cases cited in Note (1920) 8 A. L. R. 315. For cases ignoring the N. I. L. entirely, 8 id. at 317.

$5 \mathrm{I}$. For a good example of this argument carried to the extreme see Manufacturers \& Merchants Bk. v. Twelfth Street Bk., 223 Mo. App. I9I, I6 S. W. (2d) I04 (I920).

52. Holzhog v. Bakrow, 156 Ky. I61, 160 S. W. 792 (1913), 50 L. R. A. (N. s.) 1023 (I914).

53. Billington v. McColpin, 22 Ky. L. Rep. I28I, 60 S. W. 923 (1900) ; Moseley v. Selma Nat. Bk., 3 Ala. App. 614, 57 So. 91 (IOII).

54. 3 Wrlliston, Contracts (1920) \$ I677.
55. N. Y. Cons. Laws (Cahill, I930) c. 41, \$993; see also ARK. Dig. Stat. (Crawford \& Moses, I921) $\$ 4002$. The italics are the writer's.

56. Rumping v. Arkansas Nat. Bk. of Hot Springs, 121 Ark. 202, 180 S. W. 749 (1915);

Bernstein v. Fuerth, I32 Misc. 343, 229 N. Y. Supp. 79I (Manhattan Mun. Ct. 1928); cf. 
recover from a gambling maker. ${ }^{57}$ This shows clearly the weakness of the majority cases where the statute merely states that the instrument is void for gaming.

The one remaining argument in support of the majority cases on gaming statutes is that since the N. I. L. was passed to achieve uniformity, ${ }^{58}$ and since the majority of cases have held that a statute declaring an instrument void is effective against a holder in due course, all courts should now reach this conclusion even though it involves overruling previous cases. ${ }^{59}$ Although this rule is usually sound, it is clear that it must apply only to the weight of authority of cases decided after and citing the N. I. L. To hold otherwise might result simply in carrying forward common law rules that were entirely contrary to the principal purpose, or even the express wording, of the Act. ${ }^{60}$ If the courts in Alexander v. Hazelrigg and those cases which blindly followed it as the weight of authority to the effect that void meant wholly null and void as to all persons ${ }^{61}$ had properly followed the uniformity rule, they would have reached the opposite result, because as late as I9II, five years after the decision of this leading case, the weight of authority of cases under and citing the N. I. L. was clearly to the effect that voidness by statute had ceased to be a real defense under the N. I. L. ${ }^{62}$

If then the courts had properly interpreted the acts involved, a statute merely declaring an instrument void because of gaming would have no effect against a holder in due course, and it is submitted that the cases should still reach this result.

But where the gambling statute goes further and provides, in addition to the phrases quoted above, that:

"No assignment of any bill, bond, note . . . where the whole or any part of the consideration for such assignment shall arise out of any gaming transaction, shall in any manner offset the defense of the person or persons making or giving such,instrument . . . or the remedies of any person interested therein," 63 .

Kushner v. Abbott, I56 Iowa 598, I37 N. W. 913 (1912) ; Sakon v. Santini, 257 Mich. 9I, 24I N. W. I60 (1932). Contra: Manufacturers \& Merchants Bk. v. Twelfth St. Bk., 223 Mo. App. I91, 16 S. W. (2d) 104 (I929).

57. Larschen v. Lantzes, II5 Misc. 616, I89 N. Y. Supp. I37 (Ist Dep't I92I).

58. See authorities collected in BRANNAN, op. cit. supra note 2 , at 83 et seq.

59. Farmers State Bk. v. Clayton Nat. Bk., 3I N. M. 344, 245 Pac. 543, 46 A. L. R. 952 (I925), overruling Wolford v. Martinez, 28 N. M. 622, 216 Pac. 499 (I923), cited note 44, supra; see also Green, Real Defenses and the Negotiable Instruments Law (1934) 9 TulaNe L. REv. 78,85 .

60. An example of this sort is found in the cases holding that bank credit is not value under the N. I. L., a result clearly contrary to the express wording of $\$ 25$. See also Beutel, supra note 42 , at 14 .

6r. See supra note 59; (I92I) 70 U. of PA. L. REv. 52.

62. See cases collected in Brannan, Necotiable Instruments Law (2d ed. I9rI) 60; Twentieth St. Bk. v. Jacobs, 74 W. Va. 525, 82 S. E. 320, 321 (I9I4).

63. Colo. Comp. Laws (1921) $\$ 6869$. Italics are the writer's. 
the courts properly hold that both the making ${ }^{64}$ and the indorsement ${ }^{65}$ are invalid in the hands of a holder in due course. In this case it is clear that the legislature contemplated the transfer to remote parties. Even though one may quarrel with a legislative policy which penalizes innocent holders for the benefit of wrongdoers, the reconciliation of the two acts demands that the courts apply the narrow construction to the N. I. L.

\section{B. Foreign Corporations and Blue Sky Laws}

Another and more recent group of statutes designed to protect public order includes those governing the activities of foreign corporations within the state and the so-called "blue sky" laws regulating the floating of corporate financing. The general consideration of policy behind these statutes is similar to that governing the gaming statutes. Although they involve to some extent protection of the local citizen dealing with the corporations, their chief concern usually is directed toward controlling corporate activity, safeguarding the state treasury's revenue arising from incorporation fees, and assuring local citizens the right to sue the foreign business unit by prohibiting it from doing business until they have complied with the state laws. Such being the case, one would expect to find that the innocent holder in due course would be protected against the maker or drawer who created the situation, even though innocently, by entering into the forbidden transaction. It is interesting to note that most of the statutes of this sort were passed after the N. I. L., and the great majority of the courts, being unhampered by previous common law decisions, have found no difficulty in reaching a proper result, and one contrary in effect to the majority of cases under the gaming statutes.

Where the act provides that "Every sale or contract of sale made or executed in violation of any provision of this act shall be void", ${ }^{66}$ or employs words of similar import, ${ }^{67}$ with one possible exception ${ }^{68}$ the courts have no difficulty in allowing recovery by a holder in due course. ${ }^{69}$

64. Ayer v. Younker, to Colo. App. 27, 50 Pac. 218 (1897).

65. Western Nat. Bk. v. State Bk., 18 Colo. App. I28, 70 Pac. 439 (Ig02).

66. Ind. Laws I92I, c. I02, § I4.

67. ". . . shall be void at the election of the purchaser." ILL. REv. STat. (Cahill, I933) c. $32, \$ 290$.

68. The courts of Alabama have floundered badly. The court of appeals first held flatly that the holder in due course could recover under the statute declaring such contracts "null and void". Citizens' Nat. Bank v. Bucherit, I4 Ala. App. 5II, 7I So. 82 (I9I6). The supreme cuurt refused a writ of certiorari. Ig6 Ala. 700,72 So. Iorg (I9I6). Six months later the same court of appeals, apparently unconscious of the action of the supreme court, reached an opposite result. Jones v. Martin, I5 Ala. App. 675, 74 So. 761 (1917). Still later the supreme court in Paul v. Patterson Cigar Co., 210 Ala. 532, 534, 98 So. 787, 788 (I924), indulged in some dicta to the effect that a holder in due course could not recover. Hogan v. Intertype Corporation, 136 Ark. 52, 206 S. W. $5^{8}$ (1918) is sometimes cited for the contrary proposition; but that case did not involve a negotiable instrument, and also was decided under a statute merely prohibiting such transactions and not in terms making them void. See ARK. Drg. STAT. (Crawford and Moses, I92I) $\$ 1832$. In such cases the courts are unanimous that a holder in due course may recover. See Note (I92I) I2 A. L. R. I379; Ockenfels v. Boyd, 297 Fed. $6 \mathrm{I}_{4}$ (C. C. A. 8th, 1924), refusing to follow the Arkansas case.

69. Rainier v. La Rue, 83 Ind. App. 28, 147 N. E. 312 (1925) ; McGregor v. Lamont, 225 I11. App. 45I (I922). 
Even where the Act provides as follows:

"Every contract made by or on behalf of any foreign corporation affecting its liability or relating to property within the state before it shall have complied with the provisions of this act shall be void on its behalf and on behalf of its assigns, but shall be enforceable against it or them," 70

the courts have given the corporation law a narrow interpretation that "assigns" does not include holders in due course, who may still recover from the maker of the instrument under the N. I. L. ${ }^{71}$

But where the statute provides:

". . . every contract, agreement, and transaction whatsoever made or entered into by or on behalf of any such corporation within this state, or to be executed or performed within this state, shall be wholly void on behalf of such corporation and its assignees and every person deriving any interest or title therefrom, but shall be valid and enforceable against such corporation, assignee, and person," 72

it might be argued that "assigns" should be interpreted as before and that a holder in due course gets his title de novo by his purchase of a negotiable instrument and does not get "any interest or title" from the corporation. Nevertheless, a fair interpretation of the statute would certainly lead to the conclusion that the legislature intended that the holder in due course should not recover from anybody prior to the wrong-doing corporation. In such a case one might again question a legislative policy penalizing an innocent holder, but the courts should enforce the clearly expressed intent of the "blue sky" law by applying the narrow construction of the N. I. L. refusing recovery against the maker, and they have so held. ${ }^{73}$

\section{Miscellaneous Illegality Cases}

There is a large number of cases in which the courts talk about a statute as making the instrument void for illegality, when careful examination will show that the statute merely prohibits or attaches a penalty. Examples of these cases are those involving instruments created in violation of Sunday laws, and the "patent rights", "peddlers' notes" and "lightning rod" cases, where statutes require that the nature of the consideration be stated, and that when it is so stated the note shall be non-negotiable, creating a sort of notice

70. Fla. Laws 1907, c. $5717, \S 4$. The italics are the writer's. For a much similar provision, see N. D. REv. CODE ( I899) \$ 3265 .

7I. Commercial Bk. v. Jordan, 7I Fla. 566, 7I So. 760 (1916) ; National Bk. of Commerce v. Pick, 13 N. D. 74, 99 N. W. 63 (I916), both cited note 8, supra.

72. UTAH Rev. Stat. (I933) tit. I8, c. 8, \$ 5. The italics are the writer's.

73. First Nat. Bank v. Parker, 57 Utah 290, 194 Pac. 66r (I920). This case is weakened somewhat by National Bk. of Republic v. Price, 65 Utah 57, 234 Pac. 23I (1925), cited note 9, supra, holding that an alleged holder in due course in such a case had the burden of proving it and reversing the lower court for directing a verdict for the defendant. See also comment on this case, BRAXIAN, op. cit. supra note 2 , at 685 , and authorities there cited. 
to the holder. ${ }^{\text {it }}$ In the cases involving such statutes it has uniformly and properly been held that a purchaser in due course can recover from a noncomplying maker. ${ }^{75}$

Even where the Sunday law expressly provides that "all contracts made on Sunday" (with certain exceptions not here important) "are void", ${ }^{76}$ the not too strong public policy behind the act is easily overridden by the broad interpretation of the $N$. I. L. when the instrument is in the hands of a holder in due course. ${ }^{77}$ If however the statute provides, for example, that stipulations for attorneys' fees or costs shall be void, it is not surprising to find that a holder in due course recovers the amount of the note less the void fee. ${ }^{73}$ These cases can be justified not from any magic in the word void, but on the ground that illegal facts constituting the basis for the penalty appear on the face of the note, and that therefore the holder is necessarily charged with notice of the illegality.

Rural legislatures, in their desire to collect taxes or to protect the "rube" from the city "slicker", have sometimes gone further. For example, the Kentucky legislature has provided that "peddlers' notes" shall be so marked and that:

"To such notes all defenses may be made as against the original holder, whether the same be placed upon the footing of a bill of exchange or not; and all contracts for articles or rights made with a peddler without license, and all notes given for such articles or rights not having the endorsement across the face, as hereinbefore provided for, shall be null and void." 79

Here it seems that the legislature had the problem of subsequent holders in mind, and at first the courts had little difficulty applying the rule to holders in due course. ${ }^{\text {so }}$ Lately, however, apparently realizing the unwarranted hardship on innocent purchasers of such holdings, they are beginning to protect the holder in due course by preserving the broad meaning of the terms

74. For example see Wis. Laws 1903, c. 438.

75. Sunday laws: Knox v. Clifford, 38 Wis. 651 (1875); Gordon v. Levine, 197 Mass. 263,83 N. E. 86I ( $z 908$ ). Statement of nature of consideration: Samson v. Ward, I47 Wis. 48 , I32 N. W. 629 (I9II) ; Arnd v. Sjoblom, I3I Wis. 642, III N. W. 666, 10 L. R. A. (x. s.) 842 (1907) and note.

76. ALA. CODE (Ig28) §6821.

77. Moseley v. Selma Nat. Bk., 3 Ala. App. 614, 57 So. gr (19rI).

78. Leach v. Urschel, II2 Kan. 629, 2 I2 Pac. III (I923) ; Raleigh County Bk. v. Poteet, 74 W. Va. 5II, 82 S. E. 332, L. R. A. rgr5B 928 (1914) and note.

79. Ky. STAт. (Carroll, 1930) §4223.

80. Before the N. I. L. such notes were, of course, held void in the hands of a holder in due course. Burns v. Sparks, 26 Ky. 688, 82 S. W. 425 (I904). After the N. I. L. two cases were decided not involving holders in due course, in which the court treated the notes as still entirely void and cited the preceding cases. Lawson v. First Nat. Bank, 3I Ky. L. Rep. 3I8, I02 S. W. 324 (1907) ; McAfee v. Mícrcer Nat. Bk., 31 Ky. S63, 104 S. W. 287 (1907); see Citizens' Bk. v. Crittenden Record-Press, I50 Ky. 634, I50 S. W. 814 (I9I2). 
"null and void", but giving an unnecessarily narrow construction to the rest of the "peddlers' notes" statute. ${ }^{81}$

The legislative passion for punishing innocent holders has been made even clearer in Arkansas, where the statute specifically includes negotiahle instruments, prescribing their form and further providing:

"No person shall be considered an innocent holder of the same . . . and the maker may make such defenses to the collection of the sanie in the hands of any holder, and all such notes not showing on their face for what they were given, shall be absolutely void:" $\$ 2$

This is a clear example of the special statute superseding the general, and in such a situation the court has no choice other than to enforce the legislative intent. $^{83}$

As in the gaming cases, the courts in other fields where illegality and religious passion are combined occasionally have indulged in the sport of punishing the innocent holder. For example, a statute making void instruments given for the sale of intoxicating liquor in prohibition territory ${ }^{\text {st }}$ has been held to supply a good defense against a holder in due course even under the N. I. L. ${ }^{85}$ an excellent way to encourage illegal purchases of liquor. One wonders whether a court could be found today which would duplicate such a holding.

\section{Statutes Protecting Individuals or Classes}

Statutes directed toward the protection of individuals or classes of individuals fall into two groups, those which prohibit certain transactions, making their results void, and those which protect the individual contracting party by depriving him of legal capacity.

A. Usury

The principal type of statute directed toward the protection of individuals or a class of people which does not directly affect their personal capacity to contract is the usury law. Here the legislature is attempting to prevent the creditor class from exploiting its economic advantages over poor debtors. Accordingly, when a statute declares the instrument or part of it void, there is an expression of legislative intent in the usury law to protect the maker from exploitation, while in the $N$. I. L. there is an expression of intent to protect the holder in due course. The equities are also equal, the loss of

8r. Citizens' Bk. v. Crittenden Record-Press, r50 Ky. 634, I50 S. W. 8I4 (I9I2) ; Melton Electric Co. v. Central Credit Corp., 234 Ky. 469, 28 S. W. (2d) 507 (I930). In the last case the court said that a license was not required; but the case seems to be directly within the words of the statute.

82. Arkansas Sand \& H. Dig., § 493 ( 1894 ).

83. Wyatt v. Wallace, 67 Ark. 575,55 S. W. 1105 (Ig00) ; Williams v. Layes, I68 Ark. 675,27 I S. W. II (I925).

84. Miss. ANn. CODE $\$ 2085$ (Hemingway, I927).

85. Elkin Henson Grain Co. v. White, I34 Miss. 203, 98 So. 53 I (1924). 
either party by judgment for the other is the same, and although the maker, as in the gambling situations, has created the situation by taking part in an illegal transaction, it is illegal only because of the legislative desire to protect him in a situation where he is unable adequately to protect himself. Under conditions of this sort one would expect to find a larger proportion of the cases refusing recovery to the holder in due course than in the first class of cases where roidability is used only to protect public order. Fortunately, however, this is not the case, ${ }^{86}$ owing largely to the fact that the courts in this field have properly paid more attention to the very delicate degrees of variations in legislative intent.

Usury laws declaring instruments void fall readily into two classes, those declaring the whole transaction void, ${ }^{87}$ and those avoiding either a whole ${ }^{8 s}$ or part ${ }^{s 9}$ of the interest but leaving the contract valid as to the principal sum. In the latter type the mildness of the penalty shows that the legislature desires to protect the borrower but not to penalize the capitalists. Where the statute provides that contracts for illegal interest are:

"null and void as to any agreement or stipulation . . . to pay interest and no action at law to recover interest in any sum shall be maintained" 90

it is not surprising to find a court allowing the holder to recover the entire amount of the instrument, interest and all, on the ground that since the contract contained therein is partly good, the illegality is a mere defect cut off by the holder in due course. ${ }^{91}$ But in another state, where the usury statute uses almost identical words, ${ }^{92}$ the court properly refused recovery to a holder in due course upon a showing of a long series of legislative amendments attempting to prevent a narrow interpretation of the usury laws and liberal interpretations of the N. I. L. for the benefit of holders in due course. ${ }^{23}$

86. See the collection of cases both before and since the N. I. L. in Notes L. R. A. I9I8C 773; (1920) 5 A. L. R. I447.

87. E. g., N. Y. Cons. Laws (Cahill, 1930) c. 2x, §373; GA. Code (Michie, I926) $\S \S 1770(73), 1770(77)$.

88. See Ala. Code (1923) $\$ 8567 ; 2$ Cal. Gen. Laws (Deering, r93I) Act $3757, \S 2$.

89. W. VA. Code (rg3I) c. 47 , art. $6, \S 6$.

9o. 2 CAL. Gen. Laws (Deering, I93I) Act $3757, \S 2$.

9I. Baker v. Butcher, I06 Cal. App. 358, 289 Pac. 236 (1930) ; see also Community Lumber Co. v. Chute, 284 Pac. 466, 469 (Cal. App. 1930), aff'd 292 Pac. 1069 (Cal. 1930). Contra on basis of previous common law policy is Perry Savings Bk. v. Fitzgerald, I67 Iowa 446, I49 N. W. 497 (1914); Eskridge v. Thomas, 79 W. Va. 322, 91 S. E. 7, L. R. A. I918C 769 (1916).

92. "Nor shall the borrower of money at a usurious rate of interest ever in any case in law or equity be required to pay more than the principal sum borrowed." AtA. CoDE (I923) $\$ 8567$.

93. McCormick v. Fallier, 223 Ala. 8o, I34 So. 47I (I931) ; Flagg v. Florence Discount Co., 228 Ala. I53, I53 So. 177 (1934). This statutory policy has now been changed to protect the holder in due course. ALA. CODE (Supp. I032) \$ 8567. A similar and much more doubtful result was reached on the basis of long established judicial policy in Whitaker $v$. Smith, 73 S. W. (2d) I 105, I I09 (Ky. I934), three judges dissenting. 
In New York, where the statute declared the entire usurious instrument to be void, ${ }^{94}$ and whose courts had held before the N. I. L. that the holder in due course could not recover from the maker, ${ }^{95}$ an interesting problem arose. After the adoption of the N. I. L., a bank sued as holder in due course of a negotiable instrument issued originally in a usurious transaction. A divided Court of Appeals held that the bank could recover the full amount of the instrument. ${ }^{96}$ Three of the judges ${ }^{97}$ placed the decision on the ground that the state and national banking laws ${ }^{98}$ exempted banks from the effects of the state usury laws. Two judges ${ }^{99}$ concurred on the ground that the N. I. L. broadly interpreted cut off the defense of usury in the hands of a holder in due course, while the three dissenters ${ }^{100}$ thought that the state usury law as interpreted by previous decisions controlled.

Careful examination will show that both the national banking laws and the state laws cover only the original taking of usury by the banks, and also provide for "a forfeiture of the entire interest." 101 Neither statute provides for the rights of the bank as a purchaser of an instrument void for usury. The New York court, six months later, unanimously held that a bank purchasing with knowledge of usury could recover nothing, ${ }^{102}$ reversing the Appellate Division for holding that the bank was subject only to the penalties provided in the banking laws. ${ }^{103}$ These cases, it is submitted, are square holdings that the holder in due course under the $N$. I. L. cuts off the defense of usury. ${ }^{104}$ The banking law is important only to show the legislative intent that banks be treated differently from individuals.

For a short time after these decisions the New York courts held that the N. I. L. should be broadly construed, so as to protect all holders in due course, whether banks or not. ${ }^{105}$ It now appears, however, that they are giving effect to the legislative intent to place banks on a different footing from individuals and are finding individual holders in due course subject to the defense ${ }^{106}$ though the banks are not; a very delicate adjustment of the competing legislative policies.

94. N. Y. Cons. Laws (Cahill, 1930) c. 2I, § 373.

95. Chaflin v. Boorum, I22 N. Y. 385,25 N. E. 360 ( 1890$)$.

96. Schlesinger v. Gilhooly, I89 N. Y. I, 8I N. E. 619 (1907).

97. Vann, Gray and Chase. J. J.

98. See r89 N. Y. at 6, 8I N. E. at 620.

99. Willard and Bartlett, J. J.

100. Cullen, C. J., Werner and Hiscock, J. J.

10I. See note 98 , supra.

ro2. Schlesinger v. Lehmaier, I9I N. Y. 69,83 N. E. 657 (I908).

103. Schlesinger v. Lehmaier, II7 App. Div. 428, I02 N. Y. Supp. 630 (Ist Dep't 1907).

104. A federal court in New Jersey reached this result six months prior to the decision of Schlesinger v. Gilhooly, I89 N. Y. I, 8I N. E. 619 (I907), cited note 96 , supra, in Wood v. Babbitt, I49 Fed. 818 (D. N. J. 1907).

I05. Klar v. Kostink, 65 Misc. I99, II9 N. Y. Supp. 683 (Sup. Ct. I909) ; cf. Weissman v. Naitove, I25 Misc. 647,2 II N. Y. Supp. 740 (Sup. Ct. 1925).

I06. Sabine v. Paine, 223 N. Y. 401, II9 N. E. 849,5 A. L. R. I444 (IgIS). The A. L. R. annotation points out that the plaintiff, though a holder in due course, really took the instrument at its inception and that therefore this case might be distinguished, since the New 


\section{B. Capacity}

Where statutes make instruments or contracts void and at the same time limit the capacity of the individual or business unit sought to be bound, a different situation is created. The N. I. L. has drawn a sharp distinction between capacity and illegality. Under section 55 , illegality becomes a mere defect of title which is cut off by a holder in due course, but absence of capacity is a defense which seems to be preserved even against holders in due course. If this were not so it would be unnecessary for the maker and the drawer in sections 60 and $6 I$ to admit the capacity of the payee, and for the acceptor in section 62 to admit the capacity of the drawer and payee. Add to this the fact that the indorser by section 66 "warrants to all subsequent holders in due course" "that all prior parties had capacity to contract", 107 and it is clear that the framers contemplated that incapacity was to be a defense against subsequent holders in due course. ${ }^{108}$ Whether the statute declaring instruments void affects capacity or merely declares illegality resolves itself simply into an interpretation of the particular act involved. When this question is answered, if capacity is involved, the N. I. L. is clear: the holder in due course cannot recover. ${ }^{109}$ If the statute be one of prohibition only, the court is remitted to the considerations of legislative policy already discussed. ${ }^{110}$

Tork decisions hold in such a case that a holder in due course is not protected. See Weinstein, When a Bill or Note Represents an Usurious Contract (193I) 5 TULANE L. Rev. $2 \mathrm{II}$, 219 , but even so the case has properly been followed as standing for the other proposition. Wilinsky v. Schacher, 216 App. Div. 734, 214 N. Y. Supp. 252 (2d Dep't r926); see (1918) 4 CORN. L. Q. 44 (I9I8).

I07. Negotiable INSTRUMIENTS Law $\$ 65$ (3).

I08. See also $\$ 22$, preserving the defense of the infant and corporation even though allowing them to pass title.

I09. Hollman Commercial Trust v. Alden, 268 Pac. 688 (Cal. App. I928) (lunatic incurs no liability); Green v. Gunster, 154 Wis. 69, 142 N. W. 26I (1913) (drunkard); (1913) 27 HARV. L. REv. I64. In the case of corporations the question is one of ullra vires and the interpretation of the enabling statute. Henderson v. Farmers Savings Bk., I96 Iowa, 496, 202 N. W. 259 (1925). In the case of married vomen the statutes not using the term "void" have been interpreted as ineffective to prevent liability to a holder in due course. Howard v. Simpkins, 7o Ga. 322 (I883); Commercial Nat. Bank v. Kellogg, I83 N. Y. 92, 75 N. E. Iro3 (I905); Walling v. Cushman, 238 Mass. 62, I30 N. E. I75 (I921).

IIo. The question of the effect of the indorsement of one lacking capacity to pass title to the instrument is beyond the scope of this paper. See NEGotIABLE INSTRUAIENTS LAw $\$ 22$; BranNan, op. cit. supra note 2 , at $277-280,683-686$. 